\title{
The efficacy and safety of intensive statin therapy: a meta-analysis of randomized trials
}

\author{
Kiranbir Josan MD, Sumit R. Majumdar MD MPH, Finlay A. McAlister MD MSc
}

\section{ABSTRACT}

Background: Recent lipid guidelines recommend aggressive low-density lipoprotein (LDL) cholesterol lowering in patients with coronary artery disease. To clarify the evidence for this recommendation, we conducted a meta-analysis of randomized controlled trials that compared different intensities of statin therapy.

Methods: We searched electronic databases (MEDLINE, EMBASE, Cochrane Central Registery of Controlled Trials, Web of Science) for randomized controlled trials published up to July 19,2007 , that compared statin regimens of different intensities in adults with coronary artery disease and that reported cardiovascular events or mortality. Data were pooled using random-effects models to calculate odds ratios (OR).

Results: A total of 7 trials (29 395 patients) were included. Compared with less intensive statin regimens, more intensive regimens further reduced $L D L$ levels $(0.72 \mathrm{mmol} / \mathrm{L}$ reduction, $95 \%$ confidence interval $[\mathrm{Cl}] 0.60-0.84 \mathrm{mmol} / \mathrm{L})$, and reduced the risk of myocardial infarction (OR $0.83,95 \% \mathrm{Cl} 0.77-0.91$ ) and stroke (OR $0.82,95 \% \mathrm{Cl} 0.71-0.95$ ). Although there was no effect on mortality among patients with chronic coronary artery disease (OR 0.96, 95\% Cl 0.80-1.14), all-cause mortality was reduced among patients with acute coronary syndromes treated with more intensive statin regimens (OR $0.75,95 \% \mathrm{Cl}$ $0.61-0.93)$. Compared with lower intensity regimens, more intensive regimens were associated with small absolute increases in rates of drug discontinuation (2.5\%), elevated levels of aminotransferases ( $1 \%$ ) and myopathy (0.5\%), and there was no difference in noncardiovascular mortality. All 7 trials reported events by randomization arm rather than by LDL level achieved. About half of the patients treated with more intensive statin therapy did not achieve an LDL level of less than $2.0 \mathrm{mmol} / \mathrm{L}$, and none of the trials tested combination therapies.

Interpretation: Our analysis supports the use of more intensive statin regimens in patients with established coronary artery disease. There is insufficient evidence to advocate treating to particular LDL targets, using combination lipid-lowering therapy to achieve these targets or for using more intensive regimens in patients without established coronary artery disease.

Une version française de ce résumé est disponible à l'adresse www.cmaj.ca/cgi/content/full/178/5/576/DCI

CMAJ 2008;178(5):576-84

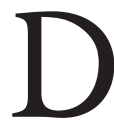
yslipidemia is the most important modifiable risk factor for myocardial infarction worldwide, ${ }^{1}$ and serum cholesterol levels are directly related to mortality from coronary artery disease in all populations studied. ${ }^{2-4}$ Over the past decade, randomized controlled trials enrolling a wide variety of patients have confirmed that for every I-mmol/L reduction in serum low-density lipoprotein (LDL) cholesterol achieved by statin therapy, the relative risks of cardiovascular events and mortality are reduced (by $2 \mathrm{I} \%$ and $\mathrm{I} 2 \%$ respectively). ${ }^{5}$

Statins exert their beneficial effects primarily by reducing the level of LDL cholesterol, ${ }^{6}$ and the reductions in the relative risk of cardiovascular events achieved by statin therapy appears to be similar regardless of baseline cholesterol levels. ${ }^{5}$ As a result, attention has increasingly focused on defining optimal target LDL levels, particularly in patients at highest risk (i.e., those with coronary artery disease). Based on the observational studies mentioned above, ${ }^{2,3}$ the apparent lack of a lower threshold for statin benefit in the randomized controlled trials, and recent trials reporting greater benefits with more intensive statin regimens (compared with less intensive regimens), Canadian ${ }^{7}$ and American $^{8}$ guidelines for secondary prevention now recommend target LDL levels below $2.0 \mathrm{mmol} / \mathrm{L}$ in patients with coronary artery disease. On the other hand, European guidelines specify a target LDL of $2.5 \mathrm{mmol} / \mathrm{L}$ in these patients. ${ }^{9}$ Questions have been raised about the safety and incremental benefits of more intensive statin regimens. ${ }^{10-12}$

We performed a systematic review and meta-analysis to critically examine the evidence for the safety, efficacy (LDL lowering) and clinical effectiveness from trials comparing more intensive statin therapy with less intensive statin therapy in patients with coronary artery disease.

\section{Methods}

\section{Eligibility criteria}

We included randomized clinical trials that compared different regimens of statin therapy intensity in adult patients with coronary artery disease and that reported cardiovascular events or mortality. We excluded studies that were only published in abstract form. We also excluded trials that com-

From the Division of General Internal Medicine, Department of Medicine, University of Alberta, Edmonton, Alta. 
pared different intensities of statin therapy but that used much lower statin doses in the control arm than currently used in clinical practice (such as the Post-CABG [Coronary Artery Bypass Graft] Trial conducted in the mid-I9gos). ${ }^{13}$

\section{Study identification and selection}

A librarian searched MEDLINE (from I966), EMBASE (from I988) and the Cochrane Central Registery of Controlled Trials using relevant subject headings, chemical abstract registry names and text-word searching for statins or hydroxymethylglutaryl-CoA reductase inhibitors (for search terms, see online Appendix I available at www.cmaj.ca/cgi/content /full/178/5/576/DC2). The search was conducted on August Io, 2006, and it was updated July I9, 2007. We also conducted a "cited-reference search" in Web of Science for all eligible papers, reviewed the reference lists of all included studies and review articles, and contacted content experts.

\section{Data extraction and quality assessment}

K.J. and F.A.M. independently screened all citations, abstracted data and assessed methodologic quality. Disagreements were resolved by consensus. All of the included trials reported composite primary outcomes, but because these differed among studies, they were not appropriate for meta-analysis. Instead, we extracted the individual outcomes from each study that were objectively defined and common among studies (e.g., death, myocardial infarction, stroke).

\section{Data analysis}

We extracted intention-to-treat data about cardiovascular events or death, and we used RevMan 4.2 (Update Software Ltd., Oxford, United Kingdom) to perform the meta-analysis of studies reporting the same outcome. We used the DerSimonian and Laird random-effects model to calculate odds ratios (OR) and the $P^{2}$ statistic to assess heterogeneity for each outcome of interest. ${ }^{14}$

\section{Results}

\section{Study selection and evaluation}

Our search identified 429 citations, of which 7 trials fulfilled our eligibility criteria (kappa $=0.70$ for agreement on study eligibility) (Figure I). ${ }^{15-21} \mathrm{We}$ excluded 2 potentially eligible trials that compared different intensities of statin therapy: I trial enrolled only patients with familial hypercholesterolemia $^{22}$ and I enrolled a wide variety of patients of whom the majority (54\%) did not have coronary artery disease. ${ }^{23}$

\section{Study characteristics}

Table I presents key characteristics from the 7 trials (reporting data from 29395 patients with coronary artery disease)

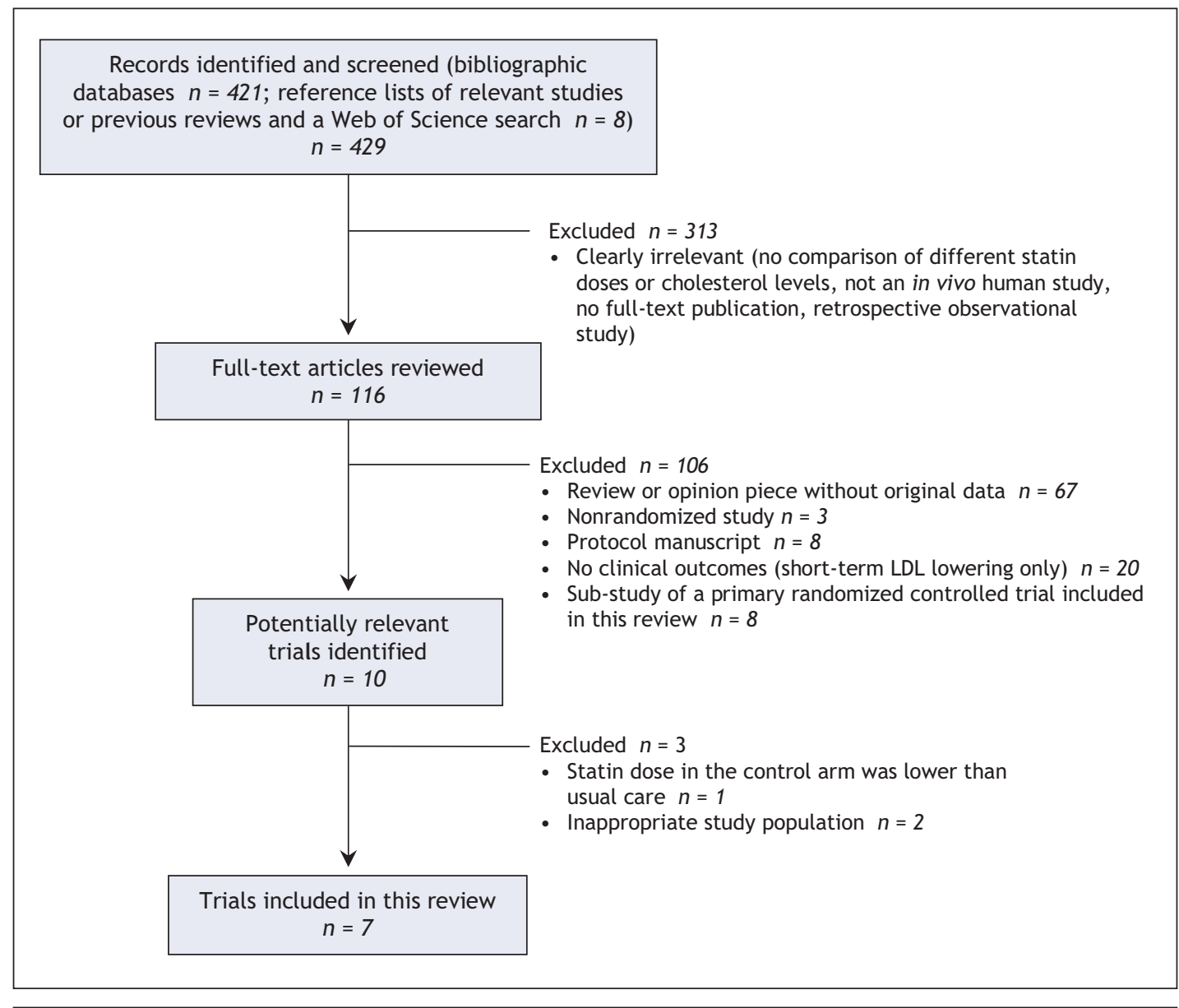

Figure 1: Flow of trials through the selection process. 
Table 1: Characteristics of 7 randomized controlled trials comparing different intensities of statin therapy included in the systematic review

\begin{tabular}{|c|c|c|c|c|c|c|c|}
\hline Characteristic & $\begin{array}{l}\text { PROVE IT-TIMI } \\
22^{15} \\
n=4162\end{array}$ & $\begin{array}{c}\text { A to } Z^{16} \\
n=4497\end{array}$ & $\begin{array}{c}\text { TNT }^{17} \\
n=10001\end{array}$ & $\begin{array}{c}\text { IDEAL }^{18} \\
n=8888\end{array}$ & $\begin{array}{c}\text { REVERSAL }^{19} \\
n=654\end{array}$ & $\begin{array}{l}\text { Vascular } \\
\text { Basis }^{20} \\
n=300\end{array}$ & $\begin{array}{l}\text { SAGE }^{21} \\
n=893\end{array}$ \\
\hline \multicolumn{8}{|l|}{ Study population } \\
\hline Age, yr, mean* & 58 & 61 (median) & 61 & 61.7 & 56 & NR & 72 \\
\hline $\begin{array}{l}\text { Male, \% of } \\
\text { participants }\end{array}$ & 78 & 76 & 81 & 80.9 & 72 & 86 & 69 \\
\hline $\begin{array}{l}\text { Diabetes, \% of } \\
\text { participants }\end{array}$ & 18 & 24 & 15 & 12 & 19 & 16 & 23 \\
\hline $\begin{array}{l}\text { Prior coronary artery } \\
\text { bypass graft surgery, } \\
\% \text { of participants }\end{array}$ & 11 & 4 & 47 & 17 & NR & 21 & 29 \\
\hline $\begin{array}{l}\text { Prior angioplasty } \\
\text { with or without } \\
\text { stent, \% of } \\
\text { participants }\end{array}$ & 15 & 45 & 54 & 20 & NR & 64 & 30 \\
\hline $\begin{array}{l}\text { Baseline LDL } \\
\text { cholesterol, mmol/L, } \\
\text { mean }\end{array}$ & 2.74 & 2.89 & $\begin{array}{l}3.9 \text { before run- } \\
\text { in; } 2.6 \text { after } \\
\text { run-in }\end{array}$ & 3.2 & 3.9 & 3.9 & 3.78 \\
\hline Population & $\begin{array}{l}\text { Post acute } \\
\text { coronary } \\
\text { syndromes }\end{array}$ & $\begin{array}{l}\text { Post acute } \\
\text { coronary } \\
\text { syndromes }\end{array}$ & $\begin{array}{l}\text { Chronic coronary } \\
\text { artery disease }\end{array}$ & $\begin{array}{l}\text { Chronic } \\
\text { coronary artery } \\
\text { disease }\end{array}$ & $\begin{array}{l}\text { Chronic } \\
\text { coronary artery } \\
\text { disease }\end{array}$ & $\begin{array}{l}\text { Chronic } \\
\text { coronary artery } \\
\text { disease }\end{array}$ & $\begin{array}{l}\text { Chronic } \\
\text { coronary artery } \\
\text { disease }\end{array}$ \\
\hline $\begin{array}{l}\text { Study groups (daily } \\
\text { dose) }\end{array}$ & $\begin{array}{l}\text { Pravastatin } \\
(40 \mathrm{mg}) \mathrm{v} \text {. } \\
\text { atorvastatin } \\
(80 \mathrm{mg})\end{array}$ & $\begin{array}{l}\text { Placebo for } 4 \\
\text { mo then } \\
\text { simvastatin } \\
(20 \mathrm{mg}) \mathrm{v} \text {. } \\
\text { simvastatin } \\
(40 \mathrm{mg} \text { for } 1 \mathrm{mo} \\
\text { then } 80 \mathrm{mg})\end{array}$ & $\begin{array}{l}\text { Atorvastatin } \\
(10 \mathrm{mg}) \mathrm{v} . \\
\text { atorvastatin } \\
(80 \mathrm{mg})\end{array}$ & $\begin{array}{l}\text { Simvastatin } \\
(20 \mathrm{mg}) \mathrm{v} \text {. } \\
\text { atorvastatin } \\
(80 \mathrm{mg})\end{array}$ & $\begin{array}{l}\text { Pravastatin } \\
(40 \mathrm{mg}) \mathrm{v} \text {. } \\
\text { atorvastatin } \\
(80 \mathrm{mg})\end{array}$ & $\begin{array}{l}\text { Lovastatin } \\
(5 \mathrm{mg}) \mathrm{v} \text {. } \\
\text { atorvastatin } \\
(80 \mathrm{mg}) \mathrm{v} \text {. } \\
\text { Atorvastatin } \\
(80 \mathrm{mg}) \text { and } \\
\text { antioxidant } \\
\text { vitamins }\end{array}$ & $\begin{array}{l}\text { Pravastatin } \\
(40 \mathrm{mg}) \mathrm{v} \text {. } \\
\text { atorvastatin } \\
(80 \mathrm{mg})\end{array}$ \\
\hline $\begin{array}{l}\text { Duration of } \\
\text { follow-up, yr }\end{array}$ & 2 & 2 & 4.9 & 4.8 & 1.5 & 1 & 1 \\
\hline Primary outcome & $\begin{array}{l}\text { Death, } \mathrm{MI} \text {, } \\
\text { unstable angina } \\
\text { requiring hospital } \\
\text { admission, } \\
\text { revascularization } \\
\text { (> } 30 \mathrm{~d} \text { after } \\
\text { randomization), } \\
\text { stroke }\end{array}$ & $\begin{array}{l}\text { Cardiovascular } \\
\text { death, nonfatal } \\
\text { MI, readmission } \\
\text { for acute } \\
\text { coronary } \\
\text { syndromes, } \\
\text { stroke }\end{array}$ & $\begin{array}{l}\text { Death from } \\
\text { coronary artery } \\
\text { disease, nonfatal } \\
\text { MI not related to } \\
\text { procedure, } \\
\text { cardiac arrest } \\
\text { with } \\
\text { resuscitation, } \\
\text { stroke }\end{array}$ & $\begin{array}{l}\text { Death from } \\
\text { coronary artery } \\
\text { disease, } \\
\text { nonfatal acute } \\
\text { MI, cardiac } \\
\text { arrest with } \\
\text { resuscitation }\end{array}$ & $\begin{array}{l}\text { Percentage } \\
\text { change in } \\
\text { atheroma } \\
\text { volume }\end{array}$ & $\begin{array}{l}\text { No. and } \\
\text { duration of } \\
\text { ischemic } \\
\text { episodes on } \\
\text { ambulatory ECG }\end{array}$ & $\begin{array}{l}\text { Total duration } \\
\text { of ischemia on } \\
\text { ambulatory } \\
\text { ECG }\end{array}$ \\
\hline \multicolumn{8}{|l|}{$\begin{array}{l}\text { Cointerventions, \% of } \\
\text { patients }\end{array}$} \\
\hline Acetylsalicylic acid & 93 & 98 & 88 & 79 & NR & 80 & 93 \\
\hline$\beta$-Blockers & 85 & 90 & 55 & 75 & NR & 81 & 75 \\
\hline ACE inhibitors & 69 & 71 & 28 & 30 & NR & 24 & 50 \\
\hline \multicolumn{8}{|l|}{ Treatment effect } \\
\hline $\begin{array}{l}\text { LDL cholesterol level } \\
\text { achieved, more } \mathrm{v} \text {. } \\
\text { less intensive } \\
\text { treatment, } \mathrm{mmol} / \mathrm{L}\end{array}$ & 1.60 v. 2.46 & 1.71 v. 2.10 & 2.0 v. 2.6 & 2.1 v. 2.7 & 2.04 v. 2.85 & 2.2 v. 3.2 & 1.70 v. 2.52 \\
\hline $\begin{array}{l}\text { Change from baseline, } \\
\text { more v. less intensive } \\
\text { treatment, \% change }\end{array}$ & 42 v. 10 & 41 v. 27 & 49 v. 33 & 34 v. 16 & 46 v. 25 & 43 v. 19 & 55 v. 32 \\
\hline $\begin{array}{l}\text { Primary outcome rate, } \\
\text { more v. less intensive } \\
\text { treatment, \% }\end{array}$ & 22.4 v. 26.3 & 14.4 v. 16.7 & 8.7 v. 10.9 & 9.3 v. 10.4 & -0.4 v. 2.7 & -29 v. -61 & -38 v. -37 \\
\hline
\end{tabular}

Note: $\mathrm{ACE}=$ angiotensin-converting enzyme, $\mathrm{A}$ to $\mathrm{Z}=$ Aggrastat to Zocor, ECG = electrocardiogram, IDEAL = Incremental Decrease in End Points Through Aggressive Lipid Lowering, $\mathrm{LDL}=$ low-density lipoprotein, $\mathrm{MI}=$ myocardial infarction, NR = not reported, PROVE IT-TIMI $22=$ Pravastatin or Atorvastatin Evaluation and Infection

Therapy-Thrombolysis in Myocardial Infarction 22, REVERSAL = Reversal of Atherosclerosis with Aggressive Lipid-Lowering Therapy, SAGE = Study Assessing Goals in the Elderly, TNT = Treating to New Targets.

*Unless stated otherwise. 
included in our review. ${ }^{15-21}$ Of these trials, 2 enrolled patients after acute coronary syndromes and 5 enrolled patients with chronic coronary artery disease. The demographic characteristics of study participants were similar across the included trials. Baseline LDL cholesterol ranged between $2.74 \mathrm{mmol} / \mathrm{L}$ in the PROVE IT-TIMI 22 (Pravastatin or Atorvastatin Evaluation and Infection Therapy-Thrombolysis in Myocardial Infarction 22) trial to $3.9 \mathrm{mmol} / \mathrm{L}$ in the REVERSAL (Reversal of Atherosclerosis with Aggressive Lipid-Lowering Therapy) trial, TNT (Treating to New Targets) trial (before the run-in period, $2.6 \mathrm{mmol} / \mathrm{L}$ before randomization) and the Vascular Basis trial. Three trials were designed with continuous outcomes as their primary outcome: the Vascular Basis and the SAGE (Study Assessing Goals in the Elderly) trials reported the number of ischemic episodes ${ }^{20,21}$ and the REVERSAL trial reported percent change in atheroma volume. ${ }^{19}$ Four trials used clinical primary composite outcomes, but the individual components differed (Table I). ${ }^{15-18}$ Of note, the definitions for several of the composite cardiovascular outcomes were different in the primary publications from the PROVE-IT and the Ato-Z (Aggrastat to Zocor) trials than those used in the other trials; however, these outcomes were re-reported by the
PROVE-IT and A-to-Z investigators (using the definitions from the other trials) in a secondary publication. ${ }^{24}$ We extracted data on "myocardial infarction or coronary death" and "stroke" for PROVE-IT and A-to-Z from this follow-up publication. ${ }^{24}$ All other outcomes were extracted from the primary study publication.

\section{Quality of included trials}

Although all 7 trials reported blinded outcome ascertainment, their Jadad scores varied from 3 to 5 (out of 5 ). Three trials adequately reported their method of allocation concealment (Table 2). ${ }^{16,18,19}$

\section{Generalizability of included trials}

Potential threats to study generalizability are reported in Table 2. For example, although the IDEAL (Incremental Decrease in End Points Through Aggressive Lipid Lowering) trial randomized over $90 \%$ of patients screened, TNT excluded almost half of those initially screened. Further, although both TNT and IDEAL included patients with stable coronary artery disease, they recruited patients from specialty clinics rather than from primary care settings. In addi-

Table 2: Quality assessment and potential risks of bias in the 7 randomized controlled trials comparing different intensity statin regimens in patients with coronary artery disease.

\begin{tabular}{|c|c|c|c|c|c|c|c|}
\hline & $\begin{array}{l}\text { PROVE IT- } \\
\text { TIMI } 22^{15} \\
n=4162\end{array}$ & $\begin{array}{c}\text { A to } Z^{16} \\
n=4497\end{array}$ & $\begin{array}{c}\text { TNT }^{17} \\
n=10001\end{array}$ & $\begin{array}{c}\text { IDEAL }^{18} \\
n=8888\end{array}$ & $\begin{array}{l}\text { REVERSAL }^{19} \\
n=654\end{array}$ & $\begin{array}{l}\text { Vascular } \\
\text { Basis }^{20} \\
n=300\end{array}$ & $\begin{array}{l}\text { SAGE }^{21} \\
n=893\end{array}$ \\
\hline $\begin{array}{l}\text { Allocation } \\
\text { concealment } \dagger\end{array}$ & Unclear & Adequate & Unclear & Adequate & Adequate & Unclear & Unclear \\
\hline $\begin{array}{l}\text { Patients recruited } \\
\text { from primary care } \\
\text { setting }\end{array}$ & Yesł & Yesł & No & No & Yes† & No & Yes \\
\hline $\begin{array}{l}\text { Intention-to-treat } \\
\text { analysis }\end{array}$ & Yes & Yes & Yes & Yes & Yes & Unclear & Yes \\
\hline $\begin{array}{l}\text { Run-in before } \\
\text { randomization }\end{array}$ & No & No & $\begin{array}{c}\text { Yes } \\
\text { (8 weeks) }\end{array}$ & No & $\begin{array}{c}\text { Yes } \\
\text { (2 weeks) }\end{array}$ & No & No \\
\hline $\begin{array}{l}\text { Receiving statins } \\
\text { before trial, \% of } \\
\text { patients }\end{array}$ & 25 & None & 100 & 76 & $\begin{array}{l}29 \text { prior to } \\
\text { wash-out }\end{array}$ & 72 & 45 \\
\hline
\end{tabular}

Note: PROVE IT-TIMI 22 = Pravastatin or Atorvastatin Evaluation and Infection Therapy-Thrombolysis in Myocardial Infarction 22, A to Z = Aggrastat to Zocor, TNT = Treating to New Targets, IDEAL = Incremental Decrease in End Points Through Aggressive Lipid Lowering, REVERSAL = Reversal of Atherosclerosis with Aggressive Lipid-Lowering Therapy, SAGE = Study Assessing Goals in the Elderly.

*The Jadad scale gives a methodologic score based on reported methods. Scores vary from 0 to 5 , with higher scores indicating higher quality.

†Allocation concealment was classified as "adequate" if the trial described randomization procedures that ensured clinicians and participants would be unaware of potential treatment assignments (e.g., if randomization was done centrally with a random number generator and varying block size so that participating clinicians could not guess what the next treatment assignment was likely to be, and if trial participants were only assigned to a group after study recruitment and baseline data were collected).

łFor patients with acute coronary syndromes or requiring coronary angiography, hospital rather than family physician’s office was defined as the primary care setting. 
tion, the percentage of patients using statins before randomization varied widely among the trials. The A-to- $Z$ trial excluded all patients who had previously received statin therapy. The TNT trial included a run-in phase such that $100 \%$ of patients had received statin therapy for at least 8 weeks before randomization.

\section{Quantitative data syntheses}

\section{LDL-cholesterol lowering efficacy}

Compared with the lower intensity arm, the higher intensity arm in each trial achieved lower LDL cholesterol levels. The differences in LDL cholesterol levels were between 0.39 and I. $0 \mathrm{mmol} / \mathrm{L}$ (weighted mean difference $0.72,95 \% \mathrm{CI}$ $0.60-0.84 \mathrm{mmol} / \mathrm{L})$. An LDL cholesterol of less than $2.0 \mathrm{mmol} / \mathrm{L}$ was achieved in about $50 \%$ of patients in the more intensive statin monotherapy groups (Table I).

\section{All-cause mortality}

The pooled analysis revealed no difference in all-cause mortality between the more or less intensive statin treatment arms in all 7 trials (OR 0.87, 95\% CI 0.74-I.03). However, there was substantial heterogeneity among trials $\left(I^{2}=42 \%\right)$, and pooling the data obscured the fact that more intensive statin therapy was associated with a $25 \%$ reduction in mortality in patients after acute coronary syndrome (based on 353 events in 8659 patients, OR $0.75,95 \%$ CI $0.6 \mathrm{I}-0.93$ ), but had no impact on mortality in patients with chronic coronary artery disease (based on 1333 events in 20734 patients, OR 0.96 , 95\% CI o.80-I.I4).
Myocardial infarction or coronary death

More intensive statin therapy led to a statistically significant reduction in myocardial infarction or coronary death (OR $0.83,95 \%$ CI 0.77-0.9I) with no heterogeneity among trials $\left(I^{2}=0 \%\right)$ (Figure 2). Examining each of these components separately confirmed that the benefits were seen in patients after acute coronary syndromes or with chronic coronary artery disease and for both nonfatal myocardial infarction (based on 1772 events in 28439 patients, OR $0.85,95 \%$ CI $0.77-0.93$ ) and coronary deaths (based on 839 events in 28439 patients, OR $0.84,95 \%$ CI $0.7 \mathrm{I}-0.98$ ).

\section{Stroke}

Although TNT was the only trial to demonstrate a significant benefit in stroke reduction, the pooled results demonstrate a statistically significant reduction in the number of strokes with more intensive statin therapy compared with less intensive therapy (OR $0.82,95 \%$ CI $0.7 \mathrm{I}-0.95$ ) with no heterogeneity among trials $\left(I^{2}=0 \%\right)$ (Figure 3$)$. The results were similar among patients with chronic coronary artery disease or with acute coronary syndromes $(p=0.2 \mathrm{I}$ for comparison between each OR).

\section{Major cardiovascular events}

Only the IDEAL, TNT, SAGE and Vascular Basis trials reported rates of major cardiovascular events (myocardial infarction, coronary death or stroke). The pooled analysis confirmed fewer major cardiovascular events in the more intensive statin treatment arm of these trials (OR 0.80 , $95 \%$ CI $0.7 \mathrm{I}-0.90, P^{2}=27 \%$ ).

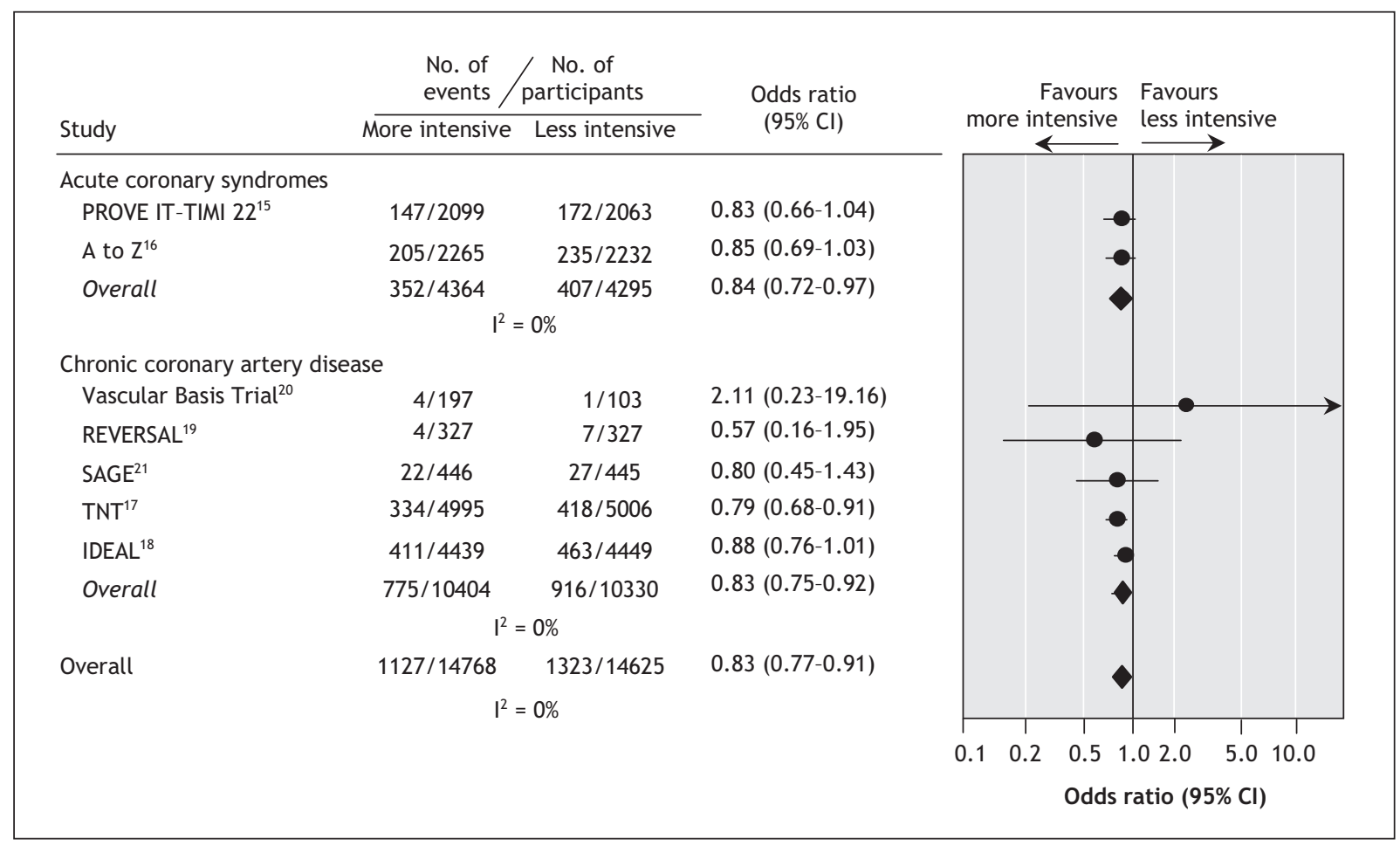

Figure 2: Risk of myocardial infarction or coronary death among patients with acute coronary syndromes or chronic coronary artery disease in 7 studies of statin therapy intensity. 


\section{Noncardiovascular mortality}

Five trials ${ }^{15-18,21}$ reported noncardiovascular mortality. There was no difference between more intensive and less intensive statin regimens in these trials (based on 670 noncardiovascular deaths in 28439 patients, OR 0.93, 95\% CI 0.69-I.25).

\section{Discontinuation rates}

Discontinuation attributed specifically to drug-related adverse events was not significantly higher with more intensive statin therapy (pooled estimate $7.8 \% \mathrm{v} .5 .3 \%$ in the less intensive statin arms) (Table 3, Table 4). To add context to the safety numbers, we have included the results from the pooled analyses of the placebo-controlled randomized statin trials (in which patients received doses similar to the "less intensive arm" of the trials reviewed in this meta-analysis) in Table $4 \cdot{ }^{11}$

\section{Aminotransferase levels}

Of the 6 trials that reported this outcome, ${ }^{15-19,21} 5$ described a significant excess risk of elevated aminotrasferase levels (aspartate aminotransferase or alanine aminotransferase levels more than 3 times the normal upper limit) with more intensive statin therapy compared with less intensive therapy (Table 3, Table 4). The pooled rates were significantly different (I.5\% v. 0.4\%, OR 4.I4, 95\% CI 2.30-7.44). ${ }^{15-18,21}$

\section{Myopathy and rhabdomyolysis}

Myopathic adverse events were inconsistently reported and were not significantly more frequent among patients receiving more intensive statin therapy compared with less intensive therapy (Table 3, Table 4). Although the event rates were low, all of these trials used statin monotherapy, not the com- bination therapy that is frequently recommended to achieve target LDL levels less than $2.0 \mathrm{mmol} / \mathrm{L}$.

\section{Sensitivity analyses}

None of the quality variables included in Table 2 influenced the study outcomes. For example, for the most frequent outcomes (myocardial infarction or coronary death), there was no difference in effect estimates for those trials with adequate allocation concealment (OR $0.85,95 \% \mathrm{CI}$ 0.77-0.97) compared to those without adequate allocation concealment (OR 0.80 , $95 \% \mathrm{CI} 0.7 \mathrm{I}-0.9 \mathrm{I})$. There were also no differences in the trials with run-in periods (OR $0.78,95 \% \mathrm{CI} 0.67-0.9 \mathrm{I})$ and those without run-in periods(OR $0.86,95 \% \mathrm{CI} 0.78-0.95)$.

\section{Interpretation}

Our systematic review demonstrates that, among patients with coronary artery disease, the provision of more intensive statin monotherapy (compared with less intensive statin therapy) reduces LDL cholesterol levels by a further $0.72 \mathrm{mmol} / \mathrm{L}$. This additional reduction in LDL cholesterol resulted in $17 \%$ fewer myocardial infarctions (absolute reduction $1.4 \%$ ) and I $8 \%$ fewer strokes (absolute reduction $0.5 \%$ ) among patients randomized to more intensive statin regimens rather than less intensive regimens. These benefits of more intensive statin monotherapy were at the expense of small absolute increases in the frequency of drug discontinuation (about $2.5 \%$ ), elevated aminotrasferase levels (about $\mathrm{I} \%$ ) and myopathy (about $0.5 \%$ ) when compared with less-intensive statin therapy (only the aminotransferase elevations were statistically significant). There was no difference in noncardiovascular mortality. All-cause mortality was not reduced

\begin{tabular}{|c|c|c|c|c|c|}
\hline \multirow[b]{2}{*}{ Study } & \multicolumn{2}{|c|}{ 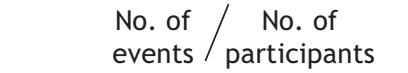 } & \multirow{2}{*}{$\begin{array}{l}\text { Odds ratio } \\
(95 \% \mathrm{CI})\end{array}$} & \multirow{2}{*}{$\begin{array}{c}\text { Favours } \\
\text { more intensive }\end{array}$} & \multirow{2}{*}{$\begin{array}{l}\text { Favours } \\
\text { less intensive } \\
\stackrel{\longrightarrow}{\longrightarrow}\end{array}$} \\
\hline & More intensive & Less intensive & & & \\
\hline \multicolumn{6}{|l|}{ Acute coronary syndrome } \\
\hline PROVE IT-TIMI $22^{15}$ & $20 / 2099$ & $17 / 2063$ & $1.16(0.60-2.22)$ & & - \\
\hline A to $Z^{16}$ & $28 / 2265$ & $35 / 2232$ & $0.79(0.48-1.30)$ & & \\
\hline Overall & $48 / 4364$ & $52 / 4295$ & $0.91(0.61-1.35)$ & & \\
\hline \multicolumn{6}{|c|}{ Chronic coronary artery disease } \\
\hline REVERSAL ${ }^{19}$ & $1 / 327$ & $1 / 327$ & $1.00(0.06-16.06)$ & $\leftarrow$ & $\rightarrow$ \\
\hline Vascular Basis Trial ${ }^{20}$ & $1 / 197$ & $1 / 103$ & $0.52(0.03-8.41)$ & $\leftarrow$ & \\
\hline $\mathrm{SAGE}^{21}$ & $1 / 446$ & $3 / 445$ & $0.33(0.03-3.20)$ & & \\
\hline TNT $^{17}$ & $117 / 4995$ & $155 / 5006$ & $0.75(0.59-0.96)$ & & \\
\hline IDEAL $^{18}$ & $151 / 4439$ & $174 / 4449$ & $0.87(0.69-1.08)$ & & \\
\hline Overall & $271 / 10404 \quad I^{2}=$ & $\% 334 / 10330$ & $0.81(0.69-0.95)$ & & \\
\hline \multirow[t]{3}{*}{ Overall } & $319 /\left.14768 \quad\right|^{2}=$ & $\% 386 / 14625$ & $0.82(0.71-0.95)$ & & \\
\hline & & & & \begin{tabular}{ll|l|l} 
& & & \\
0.1 & 0.2 & 0.5
\end{tabular} & $\begin{array}{cccc} & 1 & 1 \\
2.0 & 5.0 & 10.0\end{array}$ \\
\hline & & & & \multicolumn{2}{|c|}{ Odds ratio $(95 \% \mathrm{Cl})$} \\
\hline
\end{tabular}

Figure 3: Risk of stroke among patients with acute coronary syndromes or chronic coronary artery disease in 7 studies of statin therapy intensity. 


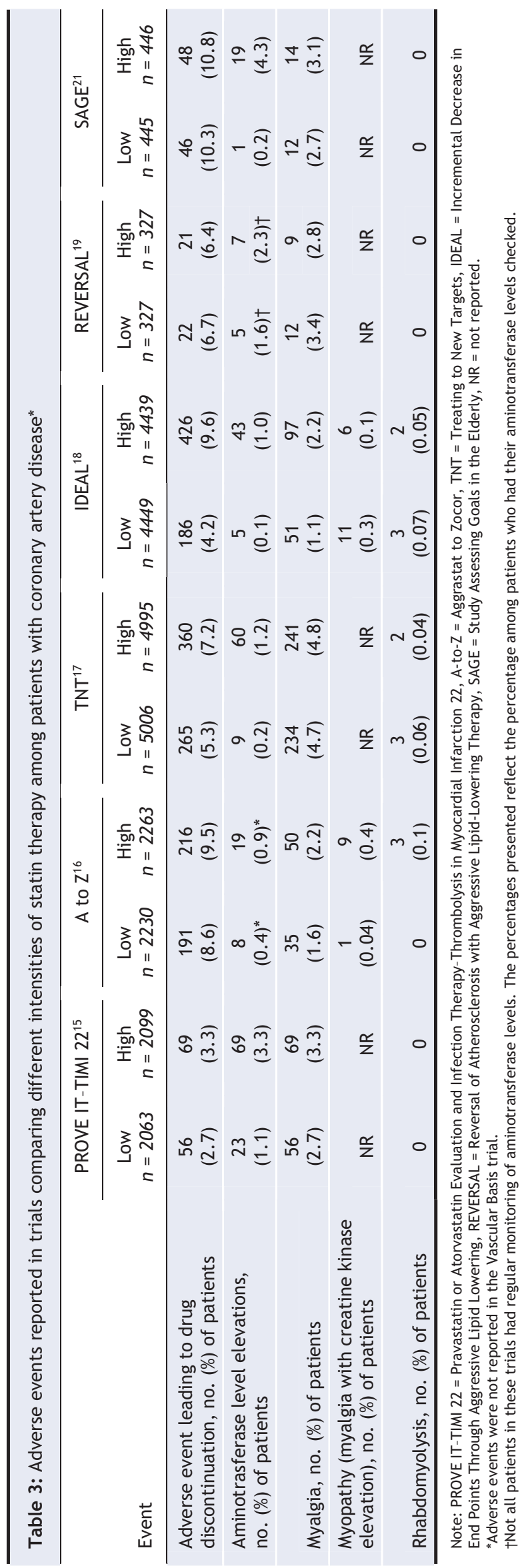

among patients with chronic coronary artery disease, but it was reduced by one-quarter among patients treated after acute coronary syndromes (absolute reduction $\mathrm{I.I} \%$, number needed to treat 9I).

Our findings have several clinical implications. First, because all of the trials compared fixed-dose regimens of more intensive statin therapy with less intensive statin therapy and because none provided a breakdown of event rates by the level of LDL cholesterol reduction achieved, the available data cannot be used to define optimal target LDL cholesterol levels. In particular, it should be noted that less than half of all patients who received more intensive statin therapy achieved LDL levels of less than $2.0 \mathrm{mmol} / \mathrm{L}$. Nonetheless, these trials support prescribing more intensive statin regimens for patients with established coronary artery disease, particularly among those with acute coronary syndromes. A recent modeling analysis confirmed that more intensive statin therapy was very costeffective among acute coronary syndrome survivors (US\$12 900 per quality-adjusted life-year). However, the incremental cost-effectiveness among patients with chronic coronary artery disease was uncertain because the small magnitude of benefits (o.Io quality-adjusted life-year) resulted in estimates that were highly sensitive to variations in drug costs and longterm adherence. ${ }^{25}$

Second, it is important to highlight that these trials provide evidence for more intensive statin monotherapy. None of these trials used, or even permitted, combination therapy. Achieving lower LDL cholesterol targets will often require the use of multidrug therapy, which may result in increased risk of adverse effects, drug-drug interactions and medication nonadherence as well as increased costs for both patients and health care payors. ${ }^{10,26}$ It is not enough that shortterm trials with LDL cholesterol outcomes have demonstrated that other lipid-lowering agents can further lower LDL cholesterol when given along with statins. ${ }^{27-29}$ Large trials are needed to establish the clinical safety and effectiveness of combination therapy.

Third, the current literature provides limited insight into whether more intensive statin therapy should be used in patients without coronary artery disease but with multiple atherosclerotic risk factors. Although 2 small trials ${ }^{22,23}$ have demonstrated reductions in carotid intima medial thickness in patients with familial hypercholesterolemia or other atherosclerostic risk factors, there were too few clinical events in these trials to make definitive conclusions. In light of a recent secondary analysis of the TNT trial which suggested that patients with metabolic syndrome may derive even greater benefits from more intensive statin therapy compared with patients without metabolic syndrome, this area of research should be a priority. ${ }^{30}$

Fourth, although the INTERHEART study and cohort studies from various regions of the world have confirmed that dyslipidemia is the most important modifiable coronary risk factor worldwide, ${ }^{1-4}$ the trials showing the efficacy of statin therapy have largely enrolled white men. For example, in our meta-analysis $88 \%-97 \%$ of study participants in the 4 trials that reported participant ethnic background were white and $69 \%-81 \%$ were men. ${ }^{15,17,19,21}$ Although it is unset- 
Table 4: Adverse events reported in trials that compared statin regimens of different intensities and those that compared statin therapy and placebo

\begin{tabular}{|c|c|c|c|c|}
\hline \multirow[b]{2}{*}{ Event } & \multicolumn{2}{|c|}{ More intensive v. less intensive statin therapy* } & \multicolumn{2}{|c|}{ Less intensive statin therapy v. placebo $\dagger$} \\
\hline & $\%$ of patients & Odds ratio $(95 \% \mathrm{Cl})$ & $\%$ of patients & Odds ratio $(95 \% \mathrm{Cl})$ \\
\hline $\begin{array}{l}\text { Adverse event leading to } \\
\text { drug discontinuation }\end{array}$ & 7.8 v. 5.3 & $1.34(0.98-1.83)$ & 5.6 v. 6.1 & $0.92(0.85-0.99)$ \\
\hline $\begin{array}{l}\text { Aminotrasferase level } \\
\text { elevation }\end{array}$ & 1.5 v. 0.4 & $4.14(2.30-7.44)$ & 1.4 v. 1.1 & $1.23(1.06-1.42)$ \\
\hline Myalgia & 3.3 v. 2.8 & $1.26(0.98-1.63)$ & 15.4 v. 18.7 & $0.79(0.76-0.83)$ \\
\hline $\begin{array}{l}\text { Myopathy (myalgia with } \\
\text { creatine kinase elevation) }\end{array}$ & 2.2 v. 1.8 & $1.91(0.11-32.13)$ & 0.9 v. 0.4 & $2.03(1.55-2.67)$ \\
\hline Rhabdomyolysis & 0.05 v. 0.04 & $0.97(0.29-3.24)$ & 0.2 v. 0.1 & $1.36(0.90-2.06)$ \\
\hline
\end{tabular}

Note: $\mathrm{Cl}=$ confidence interval.

*Data were pooled from the PROVE IT-TMI 22 (Pravastatin or Atorvastatin Evaluation and Infection Therapy-Thrombolysis in Myocardial Infarction 22), A to Z (Aggrastat to Zocor), TNT (Treating to New Targets), IDEAL (Incremental Decrease in End Points Through Aggressive Lipid Lowering), REVERSAL (Reversal of Atherosclerosis with Aggressive Lipid-Lowering Therapy) and SAGE (Study Assessing Goals in the Elderly) trials.

†These data are from a meta-analysis of 34 placebo-controlled statin trials. ${ }^{11}$

tling to discover evidence grey-zones for important demographic groups, and such findings should always stimulate research to address these evidence gaps, it is important not to deny treatment to patients in these under-researched groups. For example, although individual trials were unable to confirm the benefits of statin therapy in women, a metaanalysis that pooled individual patient data from I4 trials had sufficient outcomes to confirm that statins prevented coronary events in women (OR 0.82, 95\% CI 0.73-0.93). ${ }^{5}$ Given that "most individuals with a particular condition benefit from therapies proven to be efficacious and relative treatment effects tend to be consistent across differing baseline risks, " ${ }^{31}$ it seems reasonable to assume that groups at higher coronary risk (such as South Asians) are likely to derive the greatest absolute benefits from more intensive rather than less intensive statin therapy.

Finally, although more intensive statin therapy was well tolerated and relatively safe in the trials we reviewed, it is likely that adverse events will be more common in clinical practice for several reasons. First, trial participants are generally younger and healthier and they are more closely followed than patients in usual clinical practice. In addition, these trials excluded over half of all screened patients because of comorbidities (e.g., advanced age, renal failure, alcohol abuse, hepatic failure) or use of concomitant medications (e.g., other lipidlowering drugs, inhibitors of the cytochrome $\mathrm{P}_{45}$ o system), which may increase the risk of adverse events. ${ }^{32}$ Second, 2 of these trials only enrolled patients after they had successfully completed a run-in period without complication..$^{33}$ Third, the time frame of these randomized trials is relatively short and underscores the importance of postmarketing surveillance studies to track complication rates and drug-discontinuation rates in usual clinical practice. The ongoing SEARCH (Study of the Effectiveness of Additional Reductions in Cholesterol and Homocysteine) trial will provide much needed safety information on more intensive statin therapy (simvastatin, $80 \mathrm{mg} / \mathrm{d} \mathrm{v}$. $20 \mathrm{mg} / \mathrm{d}$ ) over a longer timeframe (I2 064 study participants, expected average follow-up of 7 years).
In summary, more intensive statin therapy is safe and welltolerated. It provides incremental benefits over and above those of lower-intensity statin therapy in the secondary prevention of myocardial infarction and stroke in patients with known coronary artery disease, irrespective of their baseline LDL cholesterol levels. Further research is needed to define optimal LDL cholesterol targets, the role of more intensive statin therapy in patients without coronary artery disease and the role of combination therapy.

\section{This article has been peer reviewed.}

Competing interests: None declared for Kiranbir Josan and Sumit Majumdar. Finlay McAlister has received funding from Pfizer Canada for an investigatorinitiated and investigator-designed trial that was peer reviewed and cofounded by the Heart and Stroke Foundation of Canada.

Contributors: All of the authors contributed to the study conception and design. Kiranbir Josan and Finlay McAlister were resposible for data acquisition and analysis. All of the authors contributed to the interpretation of the data, drafted and revised the manuscript critically, and approved the version to be published.

Acknowledgements: We thank Jeanette Buckingham MLIS for assistance with the literature search.

Finlay McAlister and Sumit Majumdar receive career salary support from the Alberta Heritage Foundation for Medical Research and the Canadian Institutes of Health Research. Finlay McAlister is also supported by the Merck Frosst/Aventis Chair in Patient Health Management at the University of Alberta. There was no project-specific funding for this study.

\section{REFERENCES}

I. Yusuf S, Hawken S, Ounpuu S, et al. Effect of potentially modifiable risk factors associated with myocardial infarction in 52 countries (the INTERHEART study): case-control study. Lancet 2004;364:937-952.

2. Verschuren WMM, Jacobs DR, Bloemberg BP, et al. Serum total cholesterol and long-term coronary heart disease mortality in different cultures. Twenty-five year follow-up of the seven countries study. JAMA I995;274:I3I-6.

3. Chen $Z$, Peto R, Collins R, et al. Serum cholesterol concentration and coronary heart disease in population with low cholesterol concentrations. BMJ I99I; 303:276-82.

4. O'Keefe JH, Cordain L, Harris WH, et al. Optimal low-density lipoprotein is 50 to $70 \mathrm{mg} / \mathrm{dl}$. Lower is better and physiologically normal. J Am Coll Cardiol 2004;43:2142-6.

5. Cholesterol Treatment Trialists' Collaborators. Efficacy and safety of cholesterollowering treatment: prospective meta-analysis of data from 90056 participants in I4 randomized trials of statins. Lancet 2005;366:1267-78. 
6. Robinson JG, Smith B, Maheshwari N, et al. Pleiotropic effects of statins: benefit beyond cholesterol reduction? A meta-regression analysis. J Am Coll Cardiol 2005;46:I855-62.

7. McPherson R, Frohlich J, Fodor G, et al. Canadian Cardiovascular Society position statement: recommendations for the diagnosis and treatment of dyslipidemia and prevention of cardiovascular disease. Can J Cardiol 2006;22:913-27.

8. Grundy SM, Cleeman JI, Merz CN, et al.; Coordinating Committee of the National Cholesterol Education Program. Implications of recent clinical trials for the $\mathrm{Na}$ tional Cholesterol Education Program Adult Treatment Panel III Guidelines. Circulation 2004; 110:227-39.

9. De Backer G, Ambrosioni E, Borch-Johnsen K, et al. European guidelines on cardiovascular disease and prevention in clinical practice. Third joint task force of European and other societies on cardiovascular disease prevention in clinical practice. Eur Heart J 2003;24:I6oI-Io.

Io. Hayward RA, Hofer TP, Vijan S. Narrative review: lack of evidence for recommended low-density lipoprotein treatment targets: a solvable problem. Ann Intern Med 2006; I45:520-30.

II. Kashani A, Phillips CO, Foody JM, et al. Risks associated with statin therapy. A systematic overview of randomized clinical trials. Circulation 2006;II4:2788-97.

I2. Armitage J. The safety of statins in clinical practice. Lancet 2007;370:178I-90.

I3. Post Coronary Artery Bypass Graft Trial Investigators. The effect of aggressive lowering of low-density lipoprotein cholesterol levels and low-dose anticoagulation on obstructive changes in saphenous-vein coronary-artery bypass grafts. $N$ Engl J Med I997;336:153-62.

I4. Higgins JPT, Thompson SG, Deeks JJ, et al. Measuring inconsistency in metaanalyses. $B M J$ 2003;327:557-60.

I5. Cannon CP, Braunwald E, McCabe CH, et al.; Pravastatin or Atorvastatin Evaluation and Infection Therapy-Thrombolysis in Myocardial Infarction 22 Investigators. Intensive versus moderate lipid lowering with statins after acute coronary syndromes. N Engl J Med 2004;350:I495-504.

I6. de Lemos JA, Blazing MA, Wiviott SD, et al; A to Z Investigators. Early intensive vs a delayed conservative simvastatin strategy in patients with acute coronary syndromes: phase $\mathrm{Z}$ of the A to Z trial. JAMA 2004;292:1307-I6.

17. LaRosa JC, Grundy SM, Waters DD, et al.; Treating to New Targets (TNT) Investigators. Intensive lipid lowering with atorvastatin in patients with stable coronary disease. N Engl J Med 2005;352:1425-35.

I8. Pedersen TR, Faergeman O, Kastelein JJ, et al.; Incremental Decrease in End Points Through Aggressive Lipid Lowering (IDEAL) Study Group. High-dose atorvastatin vs usual-dose simvastatin for secondary prevention after myocardial infarction: the IDEAL study: a randomized controlled trial. JAMA 2005;294:2437-45.

I9. Nissen SE, Tuzcu EM, Schoenhagen P, et al.; REVERSAL Investigators. Effect of intensive compared with moderate lipid-lowering therapy on progression of coronary atherosclerosis: a randomized control trial. JAMA 2004;29I:I07I-80.

20. Stone PH, Lloyd-Jones DM, Kinlay S, et al.; Vascular Basis Study Group. Effect of intensive lipid lowering, with or without antioxidant vitamins, compared with moderate lipid lowering on myocardial ischemia in patients with stable coronary artery disease: the Vascular Basis for the treatment of myocardial ischemia study. Circulation 2005;III:I747-55.
2I. Deedwania P, Stone PH, Merz NB, et al. Effects of intensive versus moderate lipidlowering therapy on myocardial ischemia in older patients with coronary heart disease. Results of the Study Assessing Goals in the Elderly (SAGE). Circulation 2007;115:700-7.

22. Smilde TJ, van Willsen $\mathrm{S}$, Wollersheim $\mathrm{H}$, et al. Effect of aggressive versus conventional lipid lowering on atherosclerosis progression in familial hypercholesterolaemia (ASAP): a prospective, randomized, double-blind trial. Lancet 200I;357:577-8I.

23. Taylor AJ, Kent SM, Flaherty PJ, et al. ARBITER: Arterial biology for the investigation of the treatment effects of reducing cholesterol: a randomized trial comparing the effects of atorvastatin and pravastatin on carotid intima medial thickness. Circulation 2002;106:2055-60.

24. Cannon CP, Steinberg BA, Murphy SA, et al. Meta-analysis of cardiovascular outcomes trials comparing intensive versus moderate statin therapy. J Am Coll Cardiol 2006;48:438-45.

25. Chan PS, Nallamothu BK, Gurm HS, et al. Incremental benefit and cost-effectiveness of high-dose statin therapy in high-risk patients with coronary artery disease. Circulation 2007; II5:2398-409.

26. Graham DJ, Staffa JA, Shatin D, et al. Incidence of hospitalized rhabdomyolysis in patients treated with lipid-lowering drugs. JAMA 2004;292:2585-90.

27. Brown BG, Zhao XQ, Chait A, et al. Simvastatin and niacin, antioxidant vitamins, or their combination for the prevention of coronary disease. N Engl J Med 200I;345: I583-92.

28. Stein E, Stender S, Mata P, et al. Achieving lipoprotein goals in patients at high risk with severe hypercholesterolemia: efficacy and safety of ezetimibe coadministered with atorvastatin. Am Heart J 2004; I48:447-55.

29. Bissonnette S, Habib R, Sampalis F, et al. Efficacy and tolerability of ezetimibe Io $\mathrm{mg} /$ day coadministered with statins in patients with primary hypercholesterolemeia who do not achieve target LDL-C while on statin monotherapy: A Canadian, multicentre, prospective study - the Ezetrol Add-On Study. Can J Cardiol 2006;22: I035-44.

30. Deedwania P, Barter P, Carmena R, et al. Reduction of low-density lipoprotein cholesterol in patients with coronary heart disease and metabolic syndrome: analysis of the Treating to New Targets Study. Lancet 2006;368:919-28.

3I. McAlister FA. Applying evidence to patient care: from black and white to shades of grey. Ann Intern Med 2003; $138: 938-9$

32. Grundy SM. The issue of statin safety. Where do we stand? Circulation 2005 III:3016-9.

33. Pablos Mendez A, Barr RG, Shea S. Run-in periods in randomized trials: implications for the application of results in clinical practice. JAMA I998;279:222-5.

Correspondence to: Dr. F. McAlister, 2E3.24 Walter C. Mackenzie Health Sciences Centre, University of Alberta Hospital, 8440 II 2

St., Edmonton AB T6G 2R7; fax 780 407-2680;

Finlay.McAlister@ualberta.ca

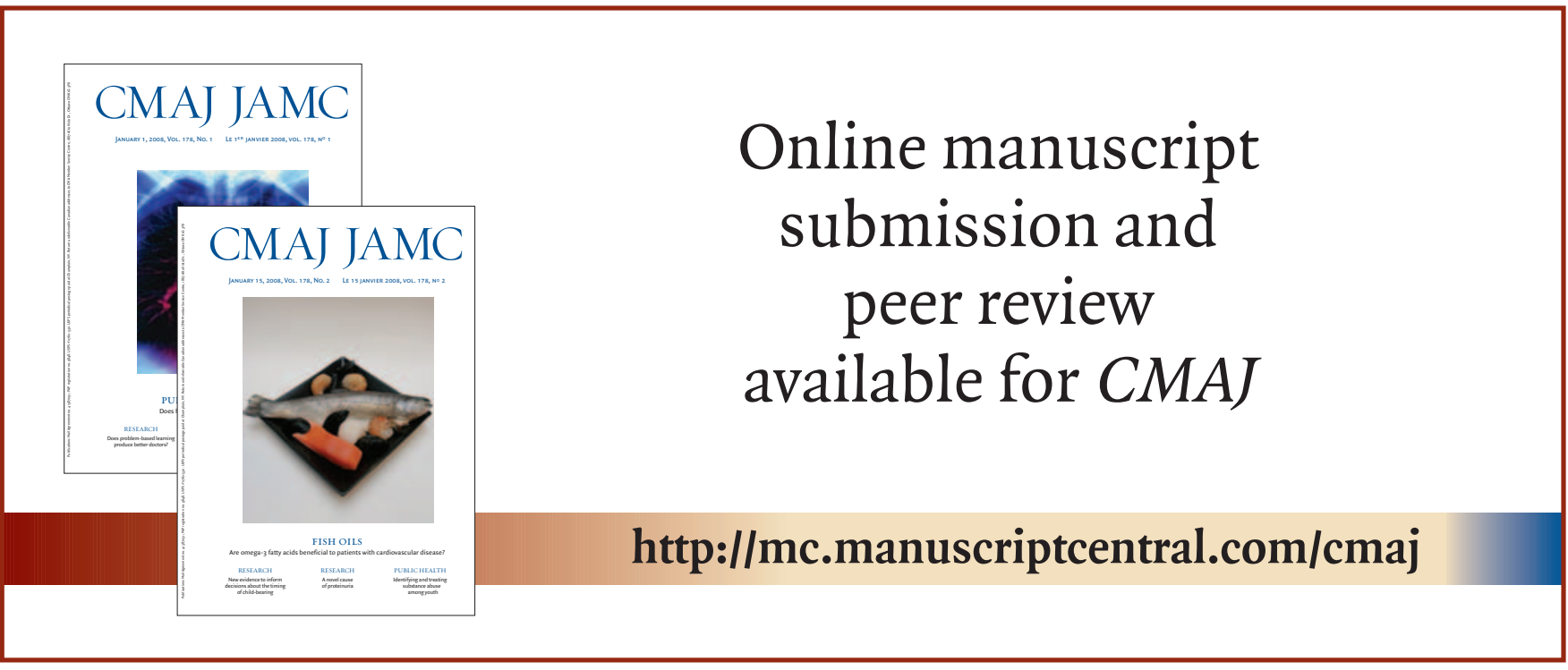

